\title{
Tussock Replacement as a Means of Stabilizing Fire Breaks in Tundra Vegetation
}

\author{
WILLIAM A. PATTERSON III' and JOHN G. DENNIS ${ }^{2}$
}

Fire generally is not considered an important factor in tundra ecosystems. Cool, moist summer weather, low plant productivity resulting in a minimum amount of fuel, and low human population densities combine to deter fires. Northwestern Alaska, and the Seward Peninsula in particular, may be exceptions to this generality. Periodic summer droughts and frequent thunderstorms during the snowfree period produced several major tundra fires in this area during the last decade (Wein, 1976; Racine and Racine, 1978). Because these fires threatened local native villages and their associated reindeer range, the U.S. Bureau of Land Management pursued an active policy of fire containment.

The use of bulldozers to scrape away surface accumulations of organic matter generally is considered an important tactic in tundra fire suppression. Narrow firebreaks are constructed ahead of advancing flames and often are successful in blocking the progress of such fires. The construction of firebreaks may, however, severely damage tundra landscapes. Removal of the protective and thermally insulating vegetative cover exposes the underlying mineral soil to increased depth of thawing and watercaused erosion. When firebreaks lie more or less on the line of fall of long slopes, channelization of runoff in the more deeply thawed soil can quickly result in formation of deep gullies. DeLeonardis (1971), for example, reported that within two years following the construction of catlines, gullies 20 to $30 \mathrm{ft}(6-9 \mathrm{~m})$ deep had formed in burned taiga vegetation underlain by permafrost in interior Alaska. He concluded from his observations that "the problems of erosion from catlines far exceeded the problems of erosion throughout the remainder of the burned-over areas" (p. 103). The mechanism underlying the type of phenomenon reported by DeLeonardis was examined by Billings (1973), who discussed how such thermokarst features can form following the accelerated rates of thaw that accompany surface disturbance in areas of permanently frozen ground.

Firefighters have recognized these dangers arising from thermokarst phenomena and have sought means of reducing post-fire thawing and erosion of firebreaks. Bolstad (1971), for example, examined the value of water bars, berm dikes, vegetative check dams and a variety of artificial seeding techniques for stabilizing firebreaks constructed on permafrost soil and concluded that most of these techniques yielded at least some success in reducing erosion. One drawback of these rehabilitation methods is that they all require substantial alteration of the landscape, either through the use of heavy equipment or through the introduction of exotic grass species and fertilization. An alternative to these methods, and one that requires less manipulation of the firebreak, was employed on a section of firebreak on the northwest border of the 1977 Imuruk Lake burn near Utica, Seward Peninsula, Alaska. The firebreak was constructed so that the cottongrass tussocks and dwarf shrub mat that covered the landscape were not destroyed. Instead, blocks of tussock and dwarf shrub/moss mat were loosened with the blade of the bulldozer and then set aside. After the fire was extinguished, the tussocks and shrub/moss mat were replaced onto the firebreak in an upright position in the hope that they would both partially insulate the soil and also reroot, thus stabilizing the site from both thermal and water erosion (Keith Woodworth, Bureau of Land Management, pers. comm.).

Because replacing tussocks is costly and timeconsuming, its effectiveness will have to be demonstrated before the practice gains widespread application. In early August 1979, we examined the 1977 firebreak at Utica and measured thaw depths within the firebreak and on adjacent burned and unburned tundra. Our study site (Fig. 1) was an area where the firebreak cut through generally homogeneous tussock tundra on a west-facing, approx-

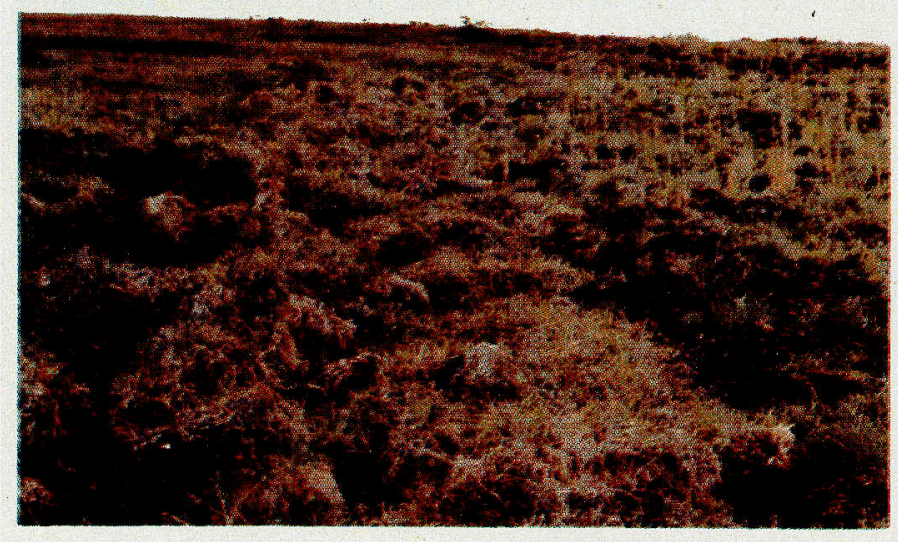

FIG. 1. View unslope of revegetated firebreak (middle), burned area (right), and unburned area (left). Note greater similarity of tussock and dwarf shrub mat vegetation of firebreak to that on the unburned site than to the tussock and Calamagrostis vegetation of the burned area. 
imately 5\% slope in the Washington Creek area northeast of Utica. We established a single, $47-\mathrm{m}$ long transect perpendicular to the firebreak and used a steel rod to measure active layer depths at $1 \mathrm{~m}$ intervals in the burned and unburned tundra, and at $20 \mathrm{~cm}$ intervals in the approximately 6-m wide firebreak.

Our results (Table 1) show that the depth of thaw under the replaced tussock and dwarf shrub mat was $22 \%$ greater than the unburned, undisturbed vegetation, and that the depth of thaw under the burned area was $40 \%$ greater than the control. These observations at Washington Creek were part of a broader investigation we were making of the effects of fire on permafrost. More than 1000 active layer measurements made throughout the area in 1977 showed that thaw depths at the end of July and beginning of August ranged from 30 to $38 \mathrm{~cm}$ on unburned sites and from 39 to $53 \mathrm{~cm}$ on sites burned in 1977. The variations observed were related to slope, aspect, and degree of burning, and within a homogeneous site variability was low. We feel, therefore, that our data adequately characterize the thaw depth relationships associated with the construction of the Washington Creek firebreak.

TABLE 1. Comparison of thaw depths on 1 August 1979 , along a transect passing from unburned tundra through a revegetated firebreak to burned tundra at Utica, Seward Peninsula, Alaska

\begin{tabular}{lcccc}
\multicolumn{1}{c}{ Treatment } & Thaw Depth (cm) & $\begin{array}{c}\text { Number of } \\
\text { Observations }\end{array}$ & $\begin{array}{c}\text { Increase as } \\
\text { Percentage } \\
\text { of Unburned }\end{array}$ & $\begin{array}{c}95 \% \\
\text { Confidence } \\
\text { Interval }\end{array}$ \\
\hline $\begin{array}{l}\text { Unburned } \\
\text { Bulldozed with }\end{array}$ & $38 \pm 6$ & 21 & - & $35-40$ \\
$\quad \begin{array}{l}\text { tussocks } \\
\quad \text { replaced }\end{array}$ & $46 \pm 6$ & 26 & 22 & $45-49$ \\
Burned & $53 \pm 8$ & 21 & 40 & $49-57$
\end{tabular}

The differences between the mean values in Table 1 are statistically significant. This suggests that, although the replacement of tussocks and dwarf shrub mat may have reduced the extent of post-fire deepening of the active layer, additional time will be required before the seasonal thawing pattern under the firebreak returns to preburn conditions. In addition, our results suggest that replacing the tussocks and dwarf shrub mat intact is apparently more effective than replacing mulched organic material, since our data show a smaller change in active layer thickness than was reported for mulching by Brown et al. (1969), who found that mulching resulted in active layer depths that were nearly twice those on undisturbed tussock tundra.

Removal of the surface vegetation mat by burning or mechanical methods reduces the albedo of the soil surface and also reduces latent heat loss (Haag and Bliss, 1974), changes which Haag and Bliss found acted in combination to increase thaw depths. According to them, replacing the vegetation layer as was done in the Utica burn would be expected to minimize the reduction in albedo, and, to the extent that the vegetation mat dries out following its replacement, also would be expected to provide insulation of the soil surface. The observations we report here support the conclusions of Haag and Bliss.

There were no nearby similar areas of firebreak where tussocks and dwarf shrub mat had not been replaced, so the erosion-reducing effect of replacing the vegetation mat compared to leaving the firebreak totally exposed could not be tested. However, many of the tussocks replaced into the firebreak showed good growth, and we estimated that in the area of our active layer transect, about $75-80 \%$ of the replaced tussock and dwarf shrub mat was alive two years after the firebreak was constructed. This length of plant survival suggests that tussock replacement is beneficial not only for keeping the active layer relatively shallow, but also for maintaining living vegetative cover to help stabilize the soil surface. Our conclusions are strengthened by observations we made in the burned area of unstabilized, wheeled-vehicle trails that had eroded to depths of greater than $100 \mathrm{~cm}$ in two years, even though slopes were generally less than $10 \%$.

Although firebreaks in tundra areas will not always be constructed in areas of tussock and dwarf shrub vegetation, the results of our study suggest that vegetation replacement or mulching should be attempted wherever the nature of the topography suggests that post-fire erosion might occur. Natural revegetation of firebreaks in tundra areas is extremely slow, and artificial stabilization techniques may be the only alternative, despite their high cost.

\section{ACKNOWLEDGEMENTS}

Our visit to the Seward Peninsula was funded in part by the U.S. Army Cold Regions Research and Engineering Laboratory and the U.S. Department of the Interior, National Park Service.

\section{REFERENCES}

BILLINGS, W.D. 1973. Arctic and alpine vegetations: Similarities, differences, and susceptibility to disturbance. Bioscience 23:697-704.

BOLSTAD, R. 1971. Catline rehabilitation and restoration. In: Slaughter, C.W., Barney, R.J. and Hansen, G.M. (eds.). Proceedings, Fire in the Northern Environment - A Symposium. U.S. Forest Service, Portland, Oregon. 107-116.

BROWN, J., RICKARD, W. and VIETOR, D. 1969. The effect of disturbance on permafrost terrain. U.S. Army Cold Regions Research and Engineering Laboratory Spec. Rept. 138. 13 p.

DeLEONARDIS, S. 1971. Effects of fire and fire control methods in interior Alaska. In: Slaughter, C.W., Barney, R.J. and Hansen, G.M. (eds.). Proceedings, Fire in the Northern Environment - A Symposium. U.S. Forest Service, Portland, Oregon. 101-105.

HAAG, R.W. and BLISS, L.C. 1974. Energy budget changes following surface disturbance to upland tundra. Journal of Applied Ecology 11:355-374.

RACINE, C.H. and RACINE, M.M. 1979. Tundra fires and two archaeological sites in the Seward Peninsula, Alaska. Arctic 32:7679.

WEIN, R.W. 1976. Frequency and characteristics of arctic tundra fires. Arctic 29:213-222. 